\title{
Intentionalitet og kunstnerisk skaben
}

\author{
Henimod en fænomenologi for den kreative proces
}

\section{Introduktion}

Inden for strukturalismen og i semiologien er vi vante til at tænke forfatteren som betinget af sproget. Inden for det semiologiske paradigme bliver sproget ikke blot tænkt som et instrument for tænkningen eller som et middel gennem hvilket forfatteren udtrykker sig selv og sine følelser, fordi mennesket - dets følelses- og tanke-liv - ikke eksisterer forud for sproget. Dets kreativitet begynder i og med sproget.

At forfatteren skaber i og med sproget bliver dog nemt til en lige så sand som tom erkendelse, der som sådan ikke formår at besvare det presserende spørgsmål: hvad vil det sige at skrive?

Lad os omformulere dette spørgsmål og istedet spørge: hvad er en skribent? Fra begyndelsen er dette spørgsmål ikke uden vigtige forudsætninger, vi forudsætter at skribenten ikke er mennesket, ikke sådan at forstå at han på nogen mystisk og/eller romantisk facon transcenderer normale menneskelige kvaliteter og vilkår, men vi undersøger blot ikke på nivauet for en generel individuel psykologi. Skribenten har et liv og gør sine erfaringer som enhver anden, men idet vi specifikt koncentrerer vor teoretiske opmærksomhed om skribenten, interesserer dette os ikke. Vort spørgsmål er fænomenologisk, idet vi spørger efter hvad skribenten er som fenomen. Hvad gør skribenten når han skriver? hvordan skulle en fænomenologi om skrift-fænomener i givet fald se ud?

Fra begyndelsen antager vi at en sådan generel teori bør være i stand til at omfatte nogle af de forskellige historiske selv-fortolkninger som vi finder hos forskellige skribenter gennem tiderne. Den bør være i stand til, indenfor sine begrebslige rammer, at inkludere historisk forskellige selv-legitimeringer og selv-fortolkninger - nærmere end at kritisere disse. 


\section{Forskellige interpretationer af den kreative proces}

En af de relativt få teoretikere som har beskæftiget sig med den kreative proces er Prag-lingvisten Jan Mukarovsky. I essayet Personality in Art ${ }^{l}$ anfægter Mukarovsky den romantiske selv-fortolkning af den kreative proces, dvs. forestillingen om kunsten som et produkt af den individuelle og private ekspressivitet, forestillingen om et enestående »psykisk privatissimum« som medium for en »mystisk »suggestiv« kraft. ${ }^{2}$ Mukarovsky kritiserer Croce for hans generalisation af denne historisk specifikke forståelse. ${ }^{3}$, samtidig med at han ignorerer helt andre forestillinger om kunstnerens rolle i f.eks. middelalderen, hvor skaberen af kunstværket typisk forbliver anonym, og hvor man end ikke bemestrer det nødvendige begrebslige sprog til at beskrive noget sådant som en privat psyke.

Sådan bliver kunstneren i middelalderen betragtet som bundet af den gældende kode og de gældende regler, hans personlighed som skaber af bestemte værker er udvisket og er ikke vigtig. Middelalderlige værker er ofte anonyme, og hvis poeten skulle prøve på at gå sine egne veje, hinsides den anbefalede imitation af det kodificerede sprog som er givet af gud, bliver han bittert irettesat og kritiseret. I denne forestilling om kunsten bliver personligheden nægtet ethvert privat udtryk.

Hos renæssancekunstneren forandres dette, forsåvidt som vi her konfronteres med en voksende selv-følelse og med et begreb om personlighed. Dette er dog stadig uligt det romantiske f.eks. derved at der ikke er nogen forestilling om kunsteren som specielt inspireret i sin kunstneriske arbejde, hævder Mukarovsky, der skriver om denne periode: $\gg V$ i finder nedsættende bemærkninger om de som tror at de kan opnå et mål ved kun at regne med sig selv, deres fantasi og så videre. ${ }^{4}$ Denne kunstner forstår endnu ikke sit værk som et psykologisk produkt, han har heller ikke begreber til rådighed til beskrivelse af det psykiske. Kreativt arbejde afhænger af dygtighed og evner. Det artistiske arbejde er ikke produceret af en intens og sensitiv sjæl som i dette arbejde udtrykker sin eget indre liv, men af et menneske som i tillid til egne evner og i kraft af bevidst vilje har besluttet sig til at skabe.

Disse upersonlige og usentimentale teorier om den kreative person forandrer sig igen i romantikken, hævder Mukarovsky. Den romantiske poet skaber ikke ud fra bevidst vilje og ikke på grund af dygtighed, værket kommer til ham i en særlig inspireret tilstand, i denne tilstand »må« han skabe. Som geni er han blevet et medium for naturlige og spontane kræfter: »noget indeni i ham skaber - »Es 
dichtet in mir « er den romantiske kunstners slogan, $\ll^{5}$ skriver Mukarovsky. I den kreative proces søger kunstneren nu kilderne til sin kunst inden i sig selv, hans indre liv er blevet kilde til hans værk, værket er derfor nu betragtet som genuint selv-udtryk. De konventionelle koder og de andres bedømmelse er for den romantiske kunstner kun hindrende for den kreative expressivitet. Han begynder at fole sig selv alieneret fra samfundet. Han har opdaget individualiteten.

Lad os fastslå at disse tre konceptioner af den kreative person som Mukarovsky udlægger dem - er historisk specifikke interpretationer, forsåvidt som de typisk forekommer indenfor historisk specifikke perioder, men at de ikke desto mindre er interpretationer af en og samme sag, nemlig den kreative proces.

Fra den kreative anonymitet, hvor den middelalderlige kunstner underkaster sig selv den konventionelle kode, over den kreative viljeskraft, hvor renæssancemennesket selvbevidst skaber sit værk, til den kreative spontanitet, hvor den romantiske kunstner gennem at lytte til sit indre selv udtrykker et værk som tvinger sig selv frem gennem ham som medium -- hvor forskellige end disse selv-fortolkninger er, behandler de ikke desto mindre den samme kreative proces. Dette er endvidere attituder, skal vi foreslå, som også bestemmer kunstværkets form og endog den specifikke periodes astetik.

$\mathrm{Ud}$ fra disse betragtninger skal vi begynde nogle overvejelser over den kreative proces.

\section{Skrivning som lytten}

I den simpleste og mest reducerede form definerer vi den kreative proces som lytten. Hvordan end kunstnerne fra forskellige perioder forstår deres egen aktivitet mens de skaber lytter de til et bestemt sprog som tilbyder sig for deres indre øre. Denne lytten er måske ikke markeret, som i middelalderen hvor kunstneren betragter sig selv som imiterende en anden, og den synes ikke markeret som en interigr lytten hos renæssancemennesket som godvilligt tager andres vurderinger $i$ betragtning mens han skaber. I romantikken synes den derimod at få status af interior lytten, idet den her bliver til en lytten til en absolut privat ekspressivitet der strømmer fra det unikke inspirerede selv hinsides noget konventionelt sprog. Ikke desto mindre, om man lytter til guddommelige regler, til fællesskabets ønsker eller til ens indre inspirerede selv, man lytter til et sprog. Dette er derfor hvad vi betragter som en absolut forudsætning for den kreative mulighed. I denne forstand er den ene historiske interpretation ikke mere sand 
end den anden.

Det romantiske credo, som Mukarovsky kritiserer så strengt, »Es dichtet in mir«, bliver nu et adækvat udtryk for den kreative erfaring. I denne sentens tematiserer romantikeren ambivalensen i den kreative situation: et eller andet - »Es«, ikke mig selv og ikke mit eget, skriver inden i mig. Dette autentiske udgangspunkt giver romantikerne en følelse af at være enestående, de har en intuition om en ubegribelig stemme som taler privat inden i dem selv uden at have nogen forbindelse med den exteriøre realitet. I det andet extrem, hos den middelalderlige kunstner, bliver selvet udvisket, enhver skaben er kodificeret, litteratur er sprog som stammer fra Gud og følgelig bliver personlige inspirationer forbudte. Værket har ingen forbindelse til individet men kun til den accepterede kode.

Romantikeren bemærker dog ikke at dette »Es« som skriver har nogen relation til »fæellesskabet«, men kun til ham selv, og han forstår følgelig sig selv i konstruktionen »geni«, én som er abstrakt inspireret. Kulminationen af denne selv-opfattelse er at den romantiske digter er den eneste autentiske person $\mathrm{i}$ verden og at hans værk udtrykker denne autenticitet.

Dette »Es dichtet in mir» synes nu at tematisere at skrift er en lytten, men uden erkendelsen af at man hermed nødvendigvis lytter til et sprog som er konventionelt, kodificeret og offentligt. Romantikeren forstår dog skriveprocessen som momentant selv-alienerende. Selvet er en beholder for noget som går for sig »indvendigt« og som er fremmed og mærkeligt, delvist hinsides den digtendes kontrol.

$\mathrm{Vi}$ skal analysere denne reflektive proces mere udførligt.

\section{Intentionalitet $i$ tonkning}

Når vi skriver tænker vi. Vi kan ikke forestille os skrift som ikke har været tænkt. Når man skriver udtrykker man sætninger for sig selv. Man fører en monolog, man kommunikerer med sig selv, man lytter kritisk til ens egne sproglige forslag, forkaster eller accepterer dem. Man benytter i denne proces et sprog som ikke er ens private og man indretter sit sprog på bestemte adækvate sprog-spil som på forhånd er bestemt af den specifikke modtager man henvender sig til. Som sådan kalder vi tænkningen på en gang den mest offentlige og den mest private mulighed.

Skrive-situationen har altså en bestemt rettethed i og med der skrives til en modtager-instans. I talehandlingen oplever vi en umiddelbar rettethed af sproget - bestemt af situation, kontext og person; man intenderer eller mener en bestemt sætning i en bestemt situation, på 
samme måde som man i Husserl's fænomenologi kan mene eller intendere et blomstrende æbletræ idet man pcrciperer det. Det blomstrende æbletræ er som intentionelt objekt perceptionens noema, dvs. det objektive ved perceptions-akterne som også har en noetisk ikke-objektiv side. Man er som intentionelt subjekt rettet mod dette og ikke mod hint. Som sådan bliver intention ikke forstået som en indre mental akt.

I "virkeligheden « er det ikke vanskeligt at forstå retningen af en tale-handling, et spørgsmål retter sig ikke alene mod den udspurgte men også mod det som der spørges efter i spørgsmålet, og yderligere ind-retter det sig indenfor den kontext hvori der tales. Denne indretning manifesterer tale-handlingens konventionelle aspekter. Jeg spørger efter saltet ved dette bord, og retter hermed ikke alcnc spørgsmålet til bestemte personer og mod det bestemte objekt, saltbøssen, mcn ind-retter også spørgsmålet efter det at vi spiser. Spørgsmålet er konventionelt acceptabelt og kontextuelt passende.

I tænkningen, som vi siger karakteriserer skrive-arbejdet par exellence, oplever vi en deprivering af denne situation. Her sidder man ikke i en bestemt kontextuel situation og man sidder ikke samlet i en dialogal situation mod andre. Det relative nærvær som præger talehandlingen, dens begivenheds-karakter, dens eneståendehed, dens nærvær og dens intentionelle rettethed, dette nærvær er ophævet $\mathrm{i}$ tænkningens abstrakte, ideale og uspontane sfære. Vi skal nu derfor prøve at analysere hvad intentionalitet er i tænkning, og derefter analysere hvad intentionalitet er i den mere specifikke situation hvorunder et kunstværk eller et teoretisk/filosofisk værk bliver til.

At tænke, har vi sagt, er at lytte til sproget. Dette er det samme som at tale til sig selv. Hermed medierer vi mellem en traditionel kløft som består mellem »privat« og »offentligt« sprog. Man er »privat « idet man taler til sig selv men »offentlig « idet man lytter til sproget, eftersom sproget ikke er ens eget private, men konventionelt. Og der er ingen forskel, ingen afstand mellem dette at tiltale sig selv og lytte til sin tiltale. Selvet og det andet er det samme. Dette samme subjekt er dog ikke desto mindre splittet mellem den talende og den lyttende. Man taler til sig selv og kommunikerer »i« sig selv mellem et »jeg« og et »mig«. Man er som det samme subjekt splittet og delt mellem den som taler og den som lytter. $\mathrm{Vi}$ opererer altså med to forskellige positioner som ikke er adskilt temporært eller spatialt. Et »jeg« og et »mig« i det samme subjekt.

Jeg er som tænkende offentlig og privat. Når jeg udtaler en sætning for mig selv bruger jeg et sprog, og når jeg former denne sætning bruger jeg min kunnen med hensyn til dette sprogs regler og kode. Jeg kender til visse regler, og når jeg skriver ved jeg hvordan man 
spiller spillet ifølge nogle regler som jeg tror at den som jeg forestiller mig jeg henvender mig til også vil kunne anerkende.

Alt dette indikerer at jeg - der i tænkningen taler så privat - ikke er ganske på egen hånd. Jeg udtrykker ikke mig selv sådan at skriften stammer fra en indre mental akt der bevæger sig »udad«: fra det uudgrundelige og intuitive følelsesliv over udtrykket for at materialisere sig i skriften. Som sådan tror vi lige så lidt som Derrida på intentioner bliver opfyldt, realiseret og aktualiseret i den materialiserede diskurs. En intention er ikke en indre plan som altid allerede er der og kun venter på at blive aktualiseret i udtrykket.

Når jeg skriver til en eller anden retter jeg diskursen til vedkommende og hermed anerkender jeg - men måske ikke med fuld opmærksomhed - det konventionelle sprog-spil som vi adlyder: dvs. mig og personen eller institutionen som inkarnerer denne bestemte diskurs. Retningen giver diskursen et indhold.

Der er en forskel mellem at skrive et postkort, et brev til skattevæsenet, en doktorafhandling osv. Skriver jeg et kort til en ven anerkender jeg samtidig den diskurs vi har sammen. Jeg iagttager, ikke personen, men den diskurs han inkorporerer. Modtageren bestemmer genren.

\section{Den imaginare modtager}

Jeg fører i skrive-handlingen en dialog med mig selv som vi kan formalisere i følgende korte formel: »jeg siger dette til mig «, en formel som formaliserer rummet mellem talen og lytten; mellem den som taler og den som lytter i det samme subjekt; mellem den som synes passiv og den som synes aktiv.

Når jeg skriver er den modtager som jeg intenderer min skriven til altså aldrig den empiriske modtager, omend denne eksisterer ganske konkret og jeg kan have vedkommende i tankerne under skrive-processen. Ikke desto mindre, modtageren $\mathrm{i}$ min skrive-akt er forst og fremmest, hvis nogetsteds, positioneret som mit »mig«. Modtageren er den som jeg forestiller mig at jeg skriver til og for, eventuelt $\mathrm{i}$ et grandiost selv-bedrag eftersom jeg kan fore en diskurs, rettet til denne formodede anden, som for denne er »upassende« eller »uheldig« (f.eks. i en ansøgningssituation hvor man ikke ved hvem man appellerer til).

Jeg retter sproget til denne imaginare modtager og denne imaginære modtager bliver den som »retter « mit sprog. Han overvåger og kontrollerer om jeg opretholder og adlyder bestemte regler i spillet. Han er dog, som imaginær, ligeså meget en del af min kreative subjektivi- 
tet som mit »jeg."

Skriften bliver produceret i dette felt af udveksling mellem et »jeg « og et »mig«, mellem en imaginær afsender og en imaginær modtager. Sådan bliver skriften produceret $\mathrm{i}$ en splittethed mellem to instanser som tilhører samme individuelle forfatter. Men eftersom begge disse instanser hver især transcenderer den individuelle skribent: i og med sproget der bruges, i og med reglerne der adlydes i sprog-spillet og endelig, i og med rettetheden mod den korrigerende anden, transcenderer de og går langt ud over skribentens privathed. Skønt skribenten ikke desto mindre aldrig har været eller bliver mere privat end netop i sin tænkning.

Det felt eller det rum mellem »jeg « og »mig« hvori skriften bliver produceret skal vi nu kalde »verden «, og hermed argumentere for at skribenten - idet han er absorberet i en skrive-proces - ikke er placeret »i« verden så meget som verden er placeret »i« ham. Det er på denne måde verden bliver ham overdraget som tradition, historie, æstetisk kode, akademisk institution, publikum osv. Det vil sige fundamentalt som sprog, endskønt denne lingvistiske indre-verden naturligvis har sit korrelat $\mathrm{i}$ og med den »virkelige« (dvs. konkrete spatio-temporale) exteriøre verden. Den »exteriøre verden« er blot aldeles uinteressant $\mathrm{i}$ undersøgelserne af det kreative cogito. Den verden som er givet for skribenten er ikke den verden der møder ham når han går ned af gaden og ser sig omkring i byen, som sådan afslører der sig ingen »verden« - forstået som tradition og historie - for ham, verden er snarere det han har last om verden. Som sådan er »verden« foranderlig. Fordi mulighedsfeltet er åbent og variationerne er uendelige for og af et givet sprog indenfor den produktive udveksling mellem »jeg« og »mig«, er det netop muligt at forandre horisonter og perspektiver. Dette ville ikke bestå som nogen mulighed for skribenten hvis vi var tvunget til at tale om en »virkelig verden. « Skribenten gør intet ved den rå materie, han skaber ud fra sproget i sproget.

I denne præcise forstand er skribenten altid betinget af verden, det er ligegyldigt om han selv tror dette eller ej. Hvis han opfatter sig som uafhængig af »realiteten« og han mener at han selv er den unikke og selv-beroende initiator af sit værk, kan han have ret i den udstrækning at den konkrete realitet ikke interesserer ham, men han kan aldrig få ret $\mathrm{i}$ at en hermeneutisk »verden « - allerede kodificeret, konventionel og historisk -- ikke allerede behersker ham. Han kan finde samfundet, politikken, religionen og hele sin tid rædselsfuld, han kan som en reaktion herpå eventuelt foretrække bjergenes ensomhed og stilhed. Men i og med denne attitude, i og med dènne negation af hans samtid, ponerer han blot sin samtid i en negativ dom. 
Som sådan skriver han blot til denne verden ressentimentfuldt.

Når Mukarovsky angriber den romantiske kreative attitude gør han hermed også et forsøg på at introducere forfatterens sociale afhængighed. Han skriver dog med et andet perspektiv end det vi har forsøgt at opstille:

„Idet han skabte sit værk tænkte kunstneren på andre mennesker som han skabte det for. Ellers ville det han skabte ikke have været et kunstværk men noget andet. For eksempel kan en skuespiller heller ikke spille for sig selv. Der er dog selvfølgelig nogen som »spiller" for sig selv og som ikke alene ikke behøver nogen tilskuere men afviser dem. Dette er barnet, men et barns aktivitet er netop noget andet end kunst, det er leg.... Kunst er skabt for andre - for læsere og tilskuere, kort sagt for iagttagere.« ${ }^{6}$

Mukarovsky skriver i en verdenslig eller en »mundan« attitude, som sådan undersøger han ikke den kreative proces som et indre-verdensligt fænomen, som noget der derfor eksklusivt vedkommer kunstneren. Han diskuterer generelt et problem der vedkommer individ og samfund i lyset af kunstneren og specielt kunstnerens sociale forpligtelser. I dette perspektiv må man sige at en bog er lavet for at blive læst, musik er komponeret for at blive hørt, et billede er malet for at blive set $o g$ så videre, og vi kan endog konkludere at hvis disse frembringelser ikke var lavet for at blive perciperet ville de ikke ifølge vore sociale og sproglige konventioner - kunne kaldes »kunst.«

Dette har imidlertid intet at gøre med det vi har kaldt den imaginare modtager, og intet at gøre med den kreative proces vi har forsøgt beskrevet. I denne proces er den fremtidige bestemmelse med det færdige produkt ligegyldig. I denne proces er skribenten social førend han end drømmer om publicering. På dette niveau taler vi måske netop om »leg« og »spil« i Mukarovsky's forstand: idet han skriver »leger«/»skriver« forfatteren netop for sig selv, han har ingen tilskuere og foretrækker så afgjort deres fravær. Han skriver i ensomhed og foretrækker denne ensomhed uden at dette gør ham helt privat i denne proces. I sin ensomme selv-beskæftigelse projekterer han netop modtager-figurer frem hvis karakteristiske sprog og sprog-spil han imiterer.

At skrive til den imaginære modtager har intet at gøre med at planlægge et skrift for udgivelse. Den imaginære modtager iagttager og overvåger altid allerede ens skrift fra sin skyggeagtige position i det kreative cogito. 


\section{"Tom intentionalitet" og "kreativ intentionalitet"}

Skriften er altså rettet til et »mig « der som den imaginære modtager, lytter til og kontrollerer og censurerer sproget og sprog-spillet. Denne rettethed mod en interiør anden, et »mig» eller en »modtager «, kalder vi intentionalitet, og hvis tænkningen ikke er mere og andet end blot rettet til dette »mig «, dvs. overhørt af et mig, skal vi kalde den »tom intentionalitet. " Tom intentionalitet er ikke investeret med nogen bestemt villen, den er blot tænkning som er »hørt.« Tænkning som ikke er hørt kender vi ikke, den forekommer ganske givet både i drømmen og i vågen adspredthed, men førend den er »hørt« er den ukendt. Ligesom drømmen ikke er kendt førend den er »hørt og har været tænkt over.

Det bevidste liv begynder altså med at tænkningen får en elementær retning mod det »mig« som hører den, sådan at personen kan siges at fortælle sig selv et eller andet. Han fortæller intet til sig selv hvis han intet hører.

Hos Mukarovsky bliver den instans vi har kaldt »mig« eller »imaginær modtager « kaldt for »den perciperende« eller »percipienten.« Denne »perciperende« er hos Mukarovsky tænkt sommetider som den reelle og empiriske modtager af teksten, sommetider som den interiøre. Sidstnævnte forståelse făr naturligvis størst relevans $\mathrm{i}$ vort perspektiv. Termen virker heldig fordi percipienten nøjagtigt er én som ser, lytter til, iagttager, overvåger, kontrollerer, kritiserer osv. diskursen. Denne percipient er ikke nødvendigvis nogen specielt, bemærker Mukarovsky, men kan, især med henblik på kunstværket, være hvem som helst. Percipienten konstituerer altså den specifikt sociale instans i det kreative subjekt, det er dets interiøre forbindelse til den exteriøre verden. Mukarovsky går sả langt som til at påstå at percipienten er originatoren af kunstværket.

»I kunsten er den fundamentale subjekt ikke originatoren men det individ til hvem det kunstneriske produkt er tiltenkt, dvs. den perciperende. For så vidt som kunstneren forudsætter en relation til sit produkt som et kunstnerisk produkt (ikke som et objekt for produktion), ser og dømmer han det endda selv som den perciperende. Den perciperende er imidlertid ikke en specifik person, ikke et bestemt individ, men hvem som helst. ${ }^{7}$ [min fremhæuning]

Vi er altså præsenteret for cn forestilling hvor percipienten, den imaginære modtager, fastholder diskursen $\mathrm{i}$ et jerngreb, kontrollerer den $\mathrm{i}$ den grad at det private »jegs« stemme reduceres til forsigtige og 
forvirrede antydninger. Det sociale har invaderet det dybt intime og private felt af enetale mellem »jeg« og »mig."

Idet vi taler om skrive-processen er der altså en uundgåelig intentionalitet på færde $\mathrm{i}$ og med sproget rettes til en modtager og indrettes efter en modtager. Sådan bliver sproget »hørt« og denne »hørthed « er en primær kvalitet ved refleksiviteten, at man »hører« sproget vil sige at man tænker på sproget. Vi har endvidere sagt at der intet skrives som der ikke har været bevidst tænkt på. Det sprog som præsenterer sig i skrift har altid været hørt, uden dog at det behøver at være investeret med mere mening end netop dette, dvs. rettetheden behøver ikke at være yderligere specificeret. Såkaldt »tom intentionalitet« har kvaliteten hørt-hed, heri får sproget ikke nogen specifik opgave at udføre. Surrealisternes såkaldte automat-skrift har, i det mindste ideelt, denne kvalitet af at have været slet og ret »hørt." Derfra er det en ren surrealistisk trossag at en sådan skrift skulle repræsentere »det ubevidste.«

$\mathrm{Nu}$ foreslår Mukarovsky en intentionalitet som er specifikt tilstede i kreativ skribentvirksomhed. Det er ikke det samme at gå rundt i lediggang og frit associere og så sætte sig for at skrive et kunstværk. I begge tilfælde »hører« man et sprog, man modtager et sprog, men i sidste tilfælde bliver intentionaliten specificeret. Det er denne specificerede intentionalitet Mukarovsky forsøger at bestemme for det kunstneriske sprog:

»Kunstværkets enhed....kan retfærdigvist kun forekomme i og med intentionaliteten, en kraft som opererer indenfor værket der streber mod oplosningen af modsigelser og spendinger mellem dets individuelle dele og komponenter, idet den hermed giver hver af dem en specifik relation til hinanden og dem alle samlet en forenet mening. Derfor er intentionalitet $i$ kunst semantisk energi. $\ll^{8}$ [mine fremhæuninger]

I kreativ skriven bliver intentionaliten en stræben efter "semantisk enhed « iflg. Mukarovsky. Man er stillet overfor den opgave at skabe et relativt autonomt kunstværk med en bestemmelse om at opfylde dets egen logik $\mathrm{i}$ en hvilken som helst af de æstetiske koder hvori denne logik bliver defineret. Intentionalitet i kreativ skriven går derfor ud over den »tomme intentionalitet", som stadig gælder som dets grund og baggrund; der er stadigvæk et »jeg« som tiltaler et lyttende "mig« - der lyttes og »høres « intenst nu, opmærksomheden er skærpet. Intentionaliteten er nu noget mere og andet end denne tomme »hørthed « som karakteriserer vort bevidste liv selv når vi går ørkeslø- 
se omkring og spilder tiden. Man vil nu orden, man stræber mod systematiseringen og »mig'et « bliver ikke blot længere en neutral modtager som lytter og tillader hvad som helst, det forvandler sig til en streng og kritisk censur-instans. Den reflektive proces, dialogen mellem "Jeg « og »mig« - subjektets monolog, stræber henimod systemet.

Mukarovsky forsøger, i sine overvejelser over kreativiteten, at godtgøre hvorfor der er denne drift henimod systemet i kreativ skriven, og han giver en løsning som får sine ressourcer fra den tidligste kritik - fra Aristoteles, Horats og Klassicismen. Intentionaliten involverer altså en »semantisk unificering« af værket og denne unificering bliver folt som »astetisk behag." Bruddet på helheden er forstyrrende, både når det iagttages af den indre modtager, "mig'et«, og når det iagttages af den reelle ydre modtager, læseren af eller publikum til kunstværket.

»Kunstens indre formål er at vekke estetisk behag, det er hinsides diskussion at ikke-intentionalitet fremtræder for os som en negativ faktor der forringer det æstetiske behag, for behag stammer fra indtrykket af en overgribende enhed af vorket, en enhed som er så lidt forstyrret som muligt. For så vidt som der indeholdes modsigelser i selve værkets struktur vil dette nødvendigvis introducere et element af ubehag i denne struktur. ${ }^{9}$ [mine fremhævninger]

Idet vi exklusivt taler om den kreative proces siger vi at intentionaliteten ind-rettes mod helheden, hvilket tager form af en vilje og en bestræbelse på at overkomme rent logiske spændinger i værket. Man ønsker at undgå modsigelser og man ønsker at opnå enhed hvilket afføder en æstetisk tilfredshed - behag eller lyst. Vi har i et par andre arbejder ${ }^{10}$ foreslået at denne tilbøjelighed efter at opnå enhed konstituerer sig selv som en relativ vilkårlig og artificiel rationalitet som reaktion imod det kreative jegs oprindelige splittethed, dets oprindelige mangel på enhed og identitet i et »kreativt cogito《som spalter sig i talende og lyttende instanser. I den kreative proces forsøger man altså at skabe orden $i$ et univers af tilfældighed. Og når kunstneren lykkes i denne bestræbelse har han overvundet modsigelser og ubestemtheder hvilket opleves som »lyst « ikke blot for ham selv men også for det perciperende publikum. Et univers af tilfældighed $o g$ vilkårlighed får orden og struktur, en verden fødes ud af kaos og det der før fremtrådte ubestemt, tilfældigt og desorganiseret er pludselig blevet symbolsk bemestret. Det vellykkede kunstværk synes nu i stand til at 
tilbyde strategier ved hjælp af hvilke man nu kan orientere sig selvi »verden.«

Dette implicerer ikke nogen normativ overvurdering af typisk konsistente kunstværker, f.eks. det græske drama eller den realistiske roman. Også i fragmentariske, aforistiske, modernistiske, i absurde, nihilistiske, revolutionære osv. kunstværker forekommer der essentielt en ordning som den vi diskuterer, dvs. en ordning af refleksionen under refleksions-processen.

At overvinde en modsigelse skal heller ikke forstås snævert logisk, sådan er der ikke tale om syllogistiske modsigelser, men om eksistentielle. Vi taler om eksistentielle betingelser der manifesterer sig som uhåndterlige, frustrerende, paradoxale etc. og som typisk deles af større kulturelle og sociale grupper. Sådan kan f.eks. den romantiske geni-konstruktion ses som en løsning på en modsigelse der fornemmes af den dannede idet han på én gang opfatter sig som mere sensitiv end borgerne og de rigeste, og samtidig er tvunget ned i samfundets nederste lag. I en situation hvor man med den dannedes selvfølelse er tvunget til at leve som en udstødt er der utvivlsomt forbundet større lyst med at være "geni« end med at være en »social taber«, en »pjalt« eller en »sut.«

Til en situation af uafgørlighed og ubestemmelighed - en situation som i skriveprocesen essentielt berører ens splittede identitet, hele spørgsmålet om ens væren og ens eksistensberettigelse - bringer kunsten ideelt orden og system. Og også den reelle iagttager og læser finder i det vellykkede kunstværk en symbolsk beherskelse af verden som ikke var tilstede for.

\section{Ikke-intentionalitet}

Det skal nu kort diskuteres hvor grænserne går for denne kontrol, denne orden og dette system som kunstvarket intenderer. Vi har indtil videre accepteret Mukarovsky's forslag at værket stræber mod »semantisk enhed « og videre adopteret forestillingen om at modtageren, percipienten - som vi fortrinsvis har forstået som internaliseret kontrollerer sproget. Men er det nu plausibelt at forestille sig at alt er under kontrol i kunsten, er kunstværket fuldstændigt intentionelt?

Dette skal vi ikke påstå, men i stedet foreslå følgende: ikke-intentionalitet optræder når »mig'et ", den interiøre iagttager, den kontrollerende instans, lader sprog passere uden at overhøre det, det vil sige når »jeg'et« $\mathrm{i}$ visse momenter taler for sig selv. Hvis et sådant »jeg« kun snakkede for sig selv uden overhøring og kontrol så ville alt være ikke-intentionelt, der ville ikke være nogen retning og organisation, 
og følgelig ingen mening.

Ikke-intentionalitet er hermed ikke identisk med ubevidsthed, men den gentagne manifestation af de samme ikke- intenderede elementer i teksten ville eventuelt (men ikke nødvendigvis) konstituere et ubevidst symptom i teksten. Dvs. hvis »mig'et«konsekvent »vælger«ikke at "se«, overvåge og kontrollere visse specifikke elementer i teksten, vil vi være tilbøjelige til, indenfor modellen: jeg siger dette til mig, at tale om »fortrængning «, eventuelt af »ubevidst" natur, eventuelt af ideologisk...osv.

Ikke-intentionalitet synes at forekomme når en komponent ikke passer i værkets semantiske helhed og enhed, den kan f.eks. manifestere sig som inkompatibilitet mellem visse elementer og værkets samlede struktur. Som sådan indikerer den ikke nødvendigvis nogen før- eller u-bevidsthed, men blot en momentan mangel på kunstnerisk mesterskab. I den forstand giver det god mening at påstå at modtageren er originator af varket, værket forstået som en enhed og et »hele« (og modtageren nødvendigvist forstået som internaliseret).

Hvis vi placerer ikke-intentionaliteten i det talende "jeg «, eller nærmere i det faktum at dette »jeg« i momenter taler uden at blive overhørt, kan vi sige at ikke-intentionalitet er et tilfælde af »tom tale« der måske stadig er rettet »tomt intentionelt «, og måske stadig hørt som slet og ret hørt, men at denne »tomme tale « ikke er forstået i en forståelse som stammer fra fuld intentionel opmærksomhed og agtpågivenhed. Ligesom man kan høre noget uden at tænke over hvad man hører, eller se noget uden at tænke over hvad man ser, eller læse noget uden at tænke over hvad man læser, kan man altså også tænke uden at tænke over hvad man tænker. Altså uden at $i$-agt-tage det hørte, det sete, det læste eller det tænkte. I den »tomme tale« med sig selv modtager man derfor ikke sproget, det passerer forbi (og modtagerinstansen er derfor delvis sat ud af spillet). I den kreative proces får det ingen dybere formål og funktion $\mathrm{i}$ helet, men fremtræder istedet som et spild eller et overskud ( $i$ alle tilfælde som en rest) i relation til værkets økonomiske struktur. Vi spørger så os selv, som publikum, hvorfor det var nødvendigt at introducere dette specielle ligegyldige $o g$ formålsløse element i koden.

\section{Konklusion}

Vi har forsøgt at gøre rede for den kreative proces som foregår under skrift-arbejdet, og introduceret forstillingen om et splittet subjekt som »meddeler" sig mellem et »jeg» og et »mig. «Vi har set på denne skribent $\mathrm{i}$ relativ isolation endskønt vi har indrømmet hans dybe sociale afhængighed. Det »kreative cogito« har været objekt for vore 
undersøgelser og vi har hævdet at som sådan problematiserer vi ikke mennesket, vi laver ikke psykologi eller psykoanalyse. I vore undersøgelser har vi fleksibelt lånt fra Mukarovsky - men ud fra et andet perspektiv end hans. Til begreber om intentionalitet og ikke-intentionalitet har vi tilføjet et begreb om »tom intentionalitet« som styrer skrive-processerne.

I modellen »jeg siger det til mig« kan vi bemærke at intentionaliteten er rettet bagud, idet den kommet efter sproget som en rekonstruktion og formning af dette sprog, mens ikke-intentionaliteten cirkulerer i systemet uden nogensinde at forankre sig i det formende »mig«, en målløs cirkulation vi har kaldt for »tom tale." Tom intentionalitet er vor betegnelse for sprogets simple og rene rettethed i skrive-processen. Forsåvidt som sproget cirkulerer i denne model (mellem »jeg « og "mig «) er positionerne i nogen grad abstrakte, ville f.eks. en sætning som allerede er intentionelt formet og nu vender tilbage til det talende »jeg « kunne siges af være »tom intentionel« idet den for anden gang sendes afsted til det censurerende "mig«? Som i alle teoretiske systemer bliver begrebsligheden abstrakt, og opstiller i det abstrakte blot nye problemer.

\section{Noter}

1. Mukarovsky in: Structure, Sign, and Function, New Haven: Yale University Press 1978.

2. Ibid., p.150.

3. I essayet $»$ Intentionality and unintentionality in art«(in: Structure, Sign, and Function): $»$ Der er hele astetiske bevagelser - Croce og hans tilhangere - som betragter kunstvarket som et entydigt udtryk for skaberens personlighed. En folelse som kun cr karakteristisk for en bestemt periode og en bestemt attitude mod kunsten som imidlertid ikke kan generaliseres« (ibid. note p.94).

4. Personality in Art, ibid., p. 153.

5. Ibid., p. 154 .

6. Ibid., p. 89 .

7. Ibid., p.94.

8. Ibid., p. 96 .

9. Ibid., p. 118.

10. Isxr Konstruktivisme - At tenke hinsides Derrida, under udgivelse, Museum Tusculanum, samt afhandlingen "Speech and System«, stencilat.

\section{Litteratur}

Mukarovsky, Jan: Structure, Sign, and Function, New Haven: Yale University Press 1978. Mukarovsky, Jan: The Word and Verbal Art, New Haven: Yale University Press 1980. De George, ed.: The Structuralists: From Marx to Levi-Strauss, New York 1972. 